\title{
Phytotoxic Effects of African Mahogany Seedlings to Herbicides
}

\author{
Luan Paz ${ }^{1}$, Caio Henrique Ferreira ${ }^{2}$, Lauricio Endres ${ }^{2}$, \\ Hugo Henrique Nascimento ${ }^{2}$, Renan de Souza ${ }^{2}$
}

${ }^{1}$ Programa de Pós-graduação em Proteção de Platas, Universidade Federal de Alagoas - UFAL, Rio Largo/AL, Brasil ${ }^{2}$ Centro de Ciências Agrárias, Universidade Federal de Alagoas - UFAL, Rio Largo/AL, Brasil

\begin{abstract}
The chemical control of weed is a common practice in silviculture. However, herbicides can potentially damage the main crop and affect its growth. The lack of information about certain species such as Khaya senegalensis make it necessary to know the phytotoxic effects of herbicides. The purpose of this research was to analyze the phytotoxic effects of five herbicides on African mahogany seedlings. The used herbicides were: saflufenacil, amicarbazone, clomazone, isoxaflutole and sulfentrazone, at doses recommended by the Ministry of Agriculture for forest species. Visual, physiological (maximum ETR, SPAD, Yield protocol and $\mathrm{F}_{\mathrm{v}} / \mathrm{F}_{\mathrm{M}}$ ) and morphological evaluations were performed up to $60 \mathrm{DAA}$. The symptoms started after 24 hours from the application; saflufenacil and clomazone were the ones that presented more plants with symptoms such as leaf wrinkling and small necrotic spots, but all of them had low phytotoxicity. The physiological evaluations did not present significant differences and the herbicides did not inhibit the growth or the appearance of new leaves. All tested herbicides caused no phytotoxicity to African mahogany seedlings.
\end{abstract}

Keywords: Khaya senegalensis, physiological parameters, chemical control. 


\section{INTRODUCTION}

One of the factors that interfere with the productivity of any agricultural or forestry crop is the presence of insects, diseases or weeds. In this sense, weeds compete with forest species for water, light, nutrients, and may also have allelopathic effects and serve as alternative hosts for insects and diseases, not to mention their contribution to forest fire incidence and negative interference in silvicultural operations (Cantarelli et al., 2006; Pereira et al., 2011). Weed interference is more severe in the period of establishment of forest crops, especially during their first year (Pitelli \& Marchi, 1998).

Brazil has one of the highest productivities and lowest cutting cycles in the forest sector, accounting for $15 \%$ of all wood harvested worldwide in approximately 7.8 million planted hectares. The most planted species in Brazil are eucalyptus and Pinus, but some species have attracted the interest of national producers, among which is African mahogany (IBA, 2016).

The genus Khaya has approximately seven species known in Brazil as African mahogany, including Khaya senegalensis. This species is native to West Africa and belongs to the family Meliaceae, the same as the Amazonian mahogany, Swietenia macrophylla, having similar characteristics in terms of wood quality (Lamprecht, 1990; Hung \& Trueman, 2011). Plantations with the genus Khaya in Brazil have gained relevance (Silva et al., 2016). According to Pinheiro et al. (2011), Khaya can be used as an alternative to Amazonian mahogany and presents advantages due to its faster initial growth and resistance to Hypsipyla grandella Zeller (Lepidoptera: Pyralidae), a pest that limits the production of Amazonian mahogany.

Chemical control is the main strategy for weed management in the conventional production system of forest species (Harker \& O'Donovan, 2013). This control involves the use of herbicides, which can be classified according to their action mechanism into groups such as: Photosystem II inhibitors, such as amicarbazone, Protoporphyrinogen Oxidase inhibitors (PROTOX), such as saflufenacil and sulfetrazone, and carotenoid biosynthesis inhibitors, such as clomazone and isoxaflutole (Mallory-Smith \& Retzinger, 2003; Grossmann et al., 2010).

In Brazil, there are 21 herbicides registered for forest crops, but none for African mahogany, according to
Agrofit, of the Ministry of Agriculture (Brasil, 2016). Tiburcio et al. (2012) state that the extension of use of registered products for other crops is important for weed management in forest crops because that allows product rotation during the productive cycle.

In order to use herbicides for weed control, caution and attention are necessary to avoid damaging the crops (Agostinetto et al., 2010). Knowing the selectivity of a product used in a crop is essential to eliminate or limit the damages caused by it to the species of interest because the use of non-selective herbicides may be more harmful than the interference promoted by weeds. Some factors that may influence selectivity include the development stage of the crop, the genetic material of the plant and the edaphoclimatic conditions at the time of application (Norsworthy et al., 2012; Braz et al., 2016).

In this sense, the purpose of this work was to evaluate the phytointoxication of five herbicides in African mahogany (Khaya senegalensis) seedlings through morphological, physiological and visual analyses.

\section{MATERIAL AND METHODS}

The research was conducted in a greenhouse at the Center of Agrarian Sciences of the Federal University of Alagoas in Rio Largo - Alagoas state, between May and August 2016.

Seeds were purchased commercially through the company Sementes Caiçara LTDA. Initially, the seeds were tested for viability. Afterwards, they were placed to germinate in seedbeds composed only of washed sand and were later transplanted to 18-liter plastic planters. The substrate used was composed of material from the municipality of Rio Largo, Alagoas state, and consisted in nine parts of soil and one of washed sand. At the end of eight months, the most vigorous seedlings were selected for the experiment, and seedlings were irrigated daily.

The experiment employed a randomized block design consisting of five herbicide treatments plus one control treatment with five replications, and the experimental unit was a seedling of African mahogany. The herbicides used in the experiment were: saflufenacil ( $98 \mathrm{~g}^{\mathrm{gha}} \mathrm{h}^{-1}$ of active ingredient), amicarbazone (1,400 g.ha ${ }^{-1}$ a.i. $)$, clomazone (1,000 g.ha ${ }^{-1}$ a.i.), isoxaflutole (263 g.ha-1 a.i.) and sulfentrazone ( 800 g.ha $^{-1}$ a.i. $)$ at the maximum doses 
for their use on forest species in Brazil recommended by the Ministry of Agriculture through the AGROFIT (Brasil, 2016).

$\mathrm{A} \mathrm{CO}_{2}$ pressurized backpack sprayer was used for application of the herbicides, equipped with a Teejet spray tip, model TTI 11002, indicated for herbicide use, with an equivalent volume of $200 \mathrm{~L}$ of spraying mixture per hectare. In the application of the herbicide, care was taken to reach every plant.

Visual evaluations were performed following the adaptation by Brancalion et al. (2009) on the EWRC grading scale (EWRC, 1964), assigning grades from 01 to 05 where 01 indicates absence of phytotoxicity and 05 , plant death. The intermediate grades corresponded to mild, moderate and severe phytotoxicity, in an ascending order. Biometric evaluations were also performed, including the number of leaves, height and diameter of the stem for volume determination, according to the formula for determination of volume of a cylinder, using a form factor for standing tree volume, as presented below (Formula 1):

Formula 1. Used volume formula:

$$
V=D^{2} * \frac{\pi}{40000} * H t * F f
$$

where:

Where $\mathrm{D}$ is the diameter of the plant stem, Ht is the total height, and the Form Factor used was 1.0, since they were at the seedling stage.

By determining the volume, it was possible to evaluate the volumetric increase during the evaluation period. The periodic current increment (PCI), corresponding to 60 days, and the weekly (WMI) and daily (DMI) mean increments were verified.

In the physiological evaluations, the top of the seedlings was divided into three thirds and one leaf was chosen per third. In every leaf, the second pair of leaflets was analyzed. The electron transport rate (ETR max.), the Yield (Y) protocol and the photosynthesis quantum yield $\left(\mathrm{F}_{\mathrm{V}} / \mathrm{F}_{\mathrm{M}}\right)$ were analyzed with a portable modulated light MINI-PAM fluorometer (Walz, Germany). For the latter, leaflets were submitted to the dark for 30 minutes, according to Rascher et al. (2000). In order to analyze chlorophyll content, all the leaflets (previously chosen in the physiological analyses) were evaluated using SPAD.
The evaluations occurred on the day of application (DAA) of the herbicides and 1, 2, 3, 7, 15, 30 and 60 days after that. The average of the thirds was used, and the morphological and visual evaluations occurred on the day of application and 7, 15, 30 and 60 DAA.

The leaf area of each plant, and then the shoot dry biomass, were determined at 60 DAA. Samples were placed in an oven with air circulation, at $65 \pm 2{ }^{\circ} \mathrm{C}$ for 72 hours, and then weighed on a precision analytical digital scale.

The obtained data were submitted to analysis of variance by the $\mathrm{F}$ test at $5 \%$ probability, and the means were compared by the Tukey's test at $5 \%$ probability, using the Assistat $7.7 \mathrm{pt}$ software. The SigmaPlot 11.0 software was used for the creation of graphs.

\section{RESULTS AND DISCUSSION}

Visual symptoms began to be observed 24 hours after the application, and $46 \%$ of the evaluated seedlings presented mild phytotoxicity symptoms, with small whitish or necrotic spots. Saflufenacil and clomazone were the herbicides causing the highest percentage of intoxicated plants, but there was no significant difference between the other treatments. Symptoms were observed on the upper third of seedlings, on young leaves and, in a single case, on the meristematic tissue. The latter was caused by isoxaflutole, and the most frequent symptoms were visible whitish or necrotic spots on the leaf limb.

The application of herbicides did not prevent the development of the treated plants; they continued to grow in height, volumetric gain and emitted new leaves. However, visually speaking, the herbicides sulfentrazone and saflufenacil were the ones that caused the most severe symptoms, such as young leave wrinkling and necrotic spots. This was also not enough to prevent growth and to cause the death of the plants.

There were no significant changes caused by the evaluated herbicides on the physiological activities of plants, as observed through the analyses of the indices SPAD, photosystem quantum yield, and Yield protocol, as shown in Figure 1.

As for the ETR, there was no significant difference between the treatments at any evaluated time. SPAD analyses on the day of the application and Yield protocol with photosystem quantum yield at 1 DAA presented 
statistical difference, but in the following analyses, the difference no longer observed. This may have occurred due to natural variation among seedlings, and not because of the use of herbicides.

In plants under normal conditions, the quantum yield of the photosystem tends to vary between 0.75 and 0.85 , and the reduction of this parameter is an ideal indicator of the photoinhibitory effect of plants under chemical stress conditions (Bolhar-Nordenkampf et al., 1989; Araus \& Hogan, 1994). The mahogany plants of this work had values varying between 0.72 and 0.79 , very close to each other, indicating no chemical stress in the seedlings treated with herbicides.

As it is possible to see in Figure 2, clomazone caused the greatest negative effects on African mahogany seedlings in terms of volumetry and leaf area, as well as the greatest visual damages. The latter were seen to be caused by saflufenacil as well, an herbicide that also affected seedlings in terms of final height at 60 DAA, although without statistical significance.

Isoxaflutole and clomazone have the same mechanism of action, but they presented opposite effects on volume increments: the first presented the smallest differences when compared to the control treatment; and the latter presented the smallest volumetric gain during the experiment. One of the explanations is the fact that isoxaflutole is considered a pro-herbicide and its performance depends on the conversion of the molecule into diketonitrile (Oliveira, 2011). There were no significant differences between treatments and control treatment.

No significant differences were observed between treatments and control treatment in terms of total dry biomass, number of leaves and final height. The number of leaves was lower between the first and the last day of observation in the treatment using saflufenacil. The greatest reduction in leaf numbers over time was

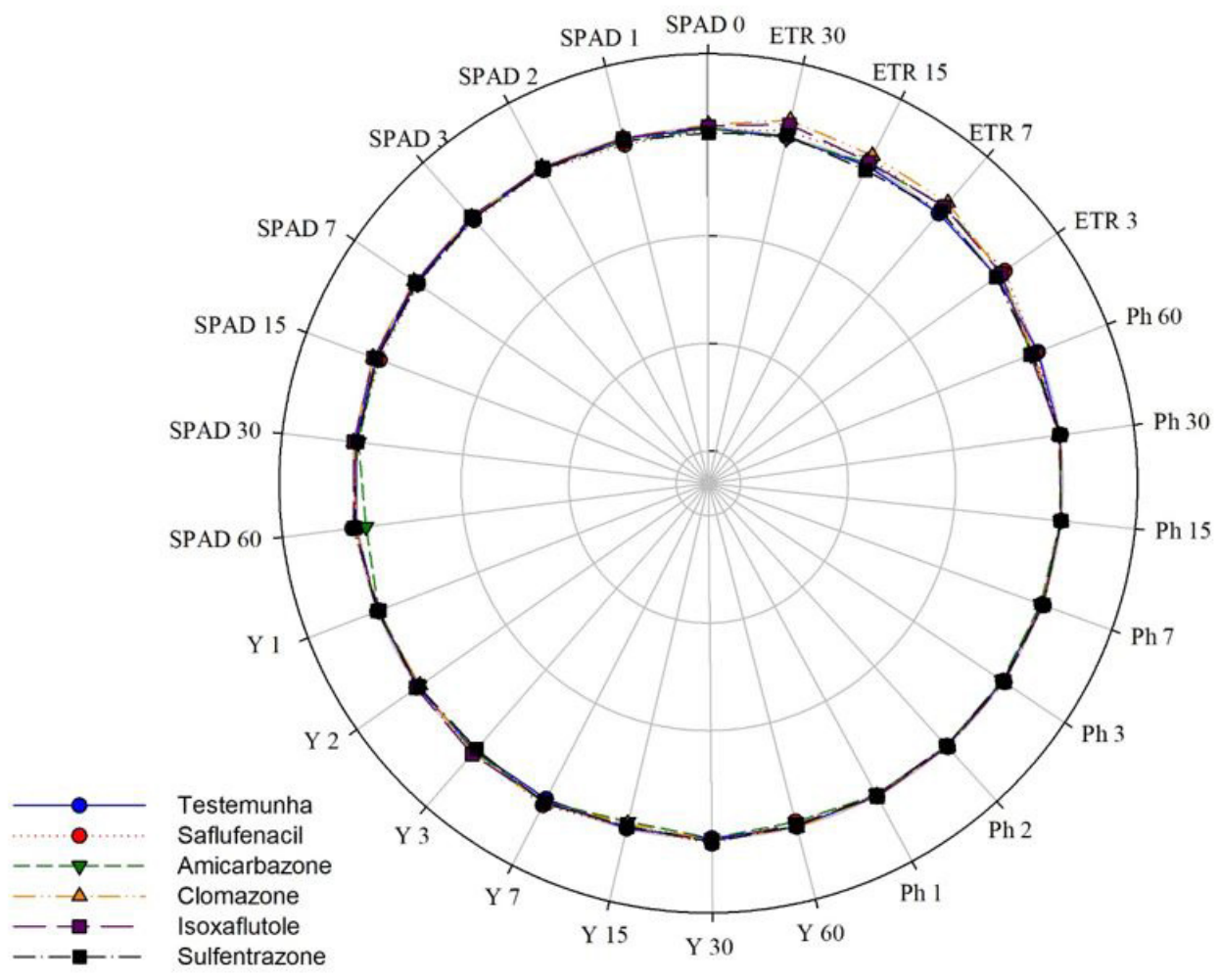

Figure 1. Physiological variables of the seedlings analyzed during the experiment. The values were transformed by dividing the means of the treatments by the mean of the control. SPAD - SPAD index, ETR - Electron Transport Rate, $\mathrm{Ph}$ - quantum yield of photosystem II, Y - Yield protocol; the numbers represent the day after application of the performed evaluation. 


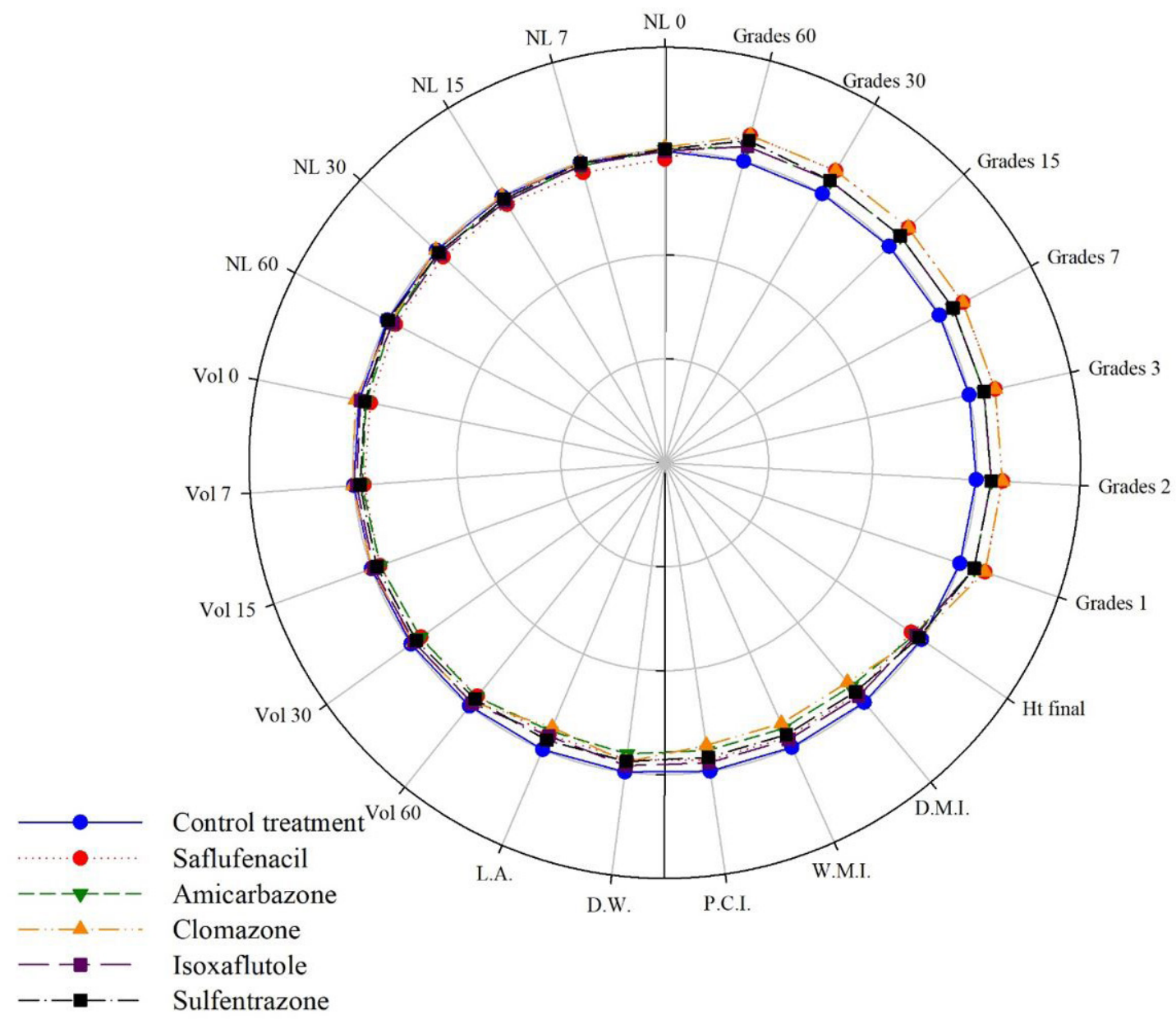

Figure 2. Biometrical variables and visual grading scale analyzed during the experiment. Values were transformed by dividing the means of the treatments by the mean of the control. NL - number of leaves, Vol - volume, LA - leaf area, DW - dry weight, PCI - periodic current increment of volume, WMI - weekly mean increment, DMI - weekly mean increment, Ht final - final total height, Grades - visual phytotoxicity grade; the number represents the day after application of the performed evaluation.

caused by clomazone. Seedlings treated with amicarbazone presented lower dry biomass than those in the other treatments. In the visual grading scale for phytotoxicity, values tended to remain constant, as shown in Figure 2.

Isoxaflutole was considered phytotoxic in the research by Brighenti \& Muller (2014) with African mahogany from the species $K$. irvorensis, as lower dry biomass and more visual damages were seen in smaller doses than the recommended maximum, differing from the control treatment. However, SPAD indices and number of leaves were similar. As for the species $K$. senegalensis, the herbicide was not considered phytotoxic, and did not differ from the control treatment in any of the analyzed variables.
Araldi et al. (2015) evaluated the effect of isoxaflutole and sulfentrazone In Guanandi seedlings and reported a $25 \%$ reduction in ETR 48 hours after the application of isoxaflutole. That result differed from the present study, where no significant differences were detected with the use of this herbicide. Sulfentrazone did not differ statistically from the control treatment in any of the two studies.

Duarte et al. (2006) used, among other herbicides, isoxaflutole and sulfentrazone on aroeira plants (Myracrodruon urundeuva) and did not verify phytotoxicity effects on height and number of leaves for these two herbicides, considering them selective to aroeira. As for African mahogany, similar results 
were found. Monquero et al. (2011) confirmed the selectivity of sulfentrazone to Luehea divaricata, as well as low herbicide phytotoxicity on Ceiba speciosa and Enterolobium contortisiliquum. Saflufenacil was considered selective to eucalyptus in a study conducted by Pereira et al. (2011); it is also considered an herbicide to be used in forest plantations and compatible with the FSC forest quality label (Zabkiewicz et al., 2010).

In a study about herbicide selectivity on native forest species, Brancalion et al. (2009) verified that isoxaflutole was selective for 20 species, including Croton floribundus, C. uirucurana, Guazuma ulmifolia, Senna multijuga. Agostinetto et al. (2010) used the same herbicide in eucalyptus and verified its selectivity for the crop.

In a study with eucalyptus, amicarbazone at high doses had the potential to reduce plant height (Cedergreen, 2008), but did not show this effect in Jatropha curcas plants, as demonstrated by Inoue et al. (2014). Such result was similar to the one found for African mahogany, since this herbicide did not affect growth significantly.

In eucalyptus, the application of clomazone caused reduction in height, shoot dry matter and leaf area, according to Takahashi et al. (2009); this last variable presented a similar result to African mahogany.

\section{CONCLUSION}

Under the studied conditions, no one of the tested herbicides cause phytotoxicity to African mahogany seedlings at the age of eight months.

\section{SUBMISSION STATUS}

Received: 19 july, 2017

Accepted: 27 oct., 2017

\section{CORRESPONDENCE TO}

\section{Luan Paz}

Programa de Pós-graduação em Proteção de Plantas, Universidade Federal de Alagoas UFAL, Rodovia BR 104, Km 85, CEP 57072-970, Maceio, AL, Brasil e-mail: luancpaz@hotmail.com; luancpaz@ig.com.br

\section{REFERENCES}

Agostinetto D, Tarouco CP, Markus C, Oliveira E, Silva JMBV, Tironi SP. Seletividade de genótipos de eucalipto a doses de herbicidas. Semina: Ciências Agrárias 2010; 31(3): $585-$ 598. http://dx.doi.org/10.5433/1679-0359.2010v31n3p585.

Araldi R, Corniani N, Tropaldi L, Girotto M, Belapart D, Simoes PS et al. Chlorophyll fluorescence in guanandi tree (Calophyllum brasiliense) after herbicide application. Planta Daninha 2015; 33(1): 77-82. http://dx.doi.org/10.1590/ S0100-83582015000100009.

Araus JL, Hogan KP. Comparative leaf structure and patterns of photoinhibition of the neotropical palms. Scheelea zonensis and Socratea durissima growing in clearing and forest understory during the dry season in Panama. American Journal of Botany 1994; 81(6): 726-738.

Bolhar-Nordenkampf HR, Long SP, Baker NR, Oquist G, Schreiber ULEG, Lechner EG. Chlorophyll fluorescence as a probe of the photosynthetic competence of leaves in the field: a review of current instrumentation. Functional Ecology 1989; 3(4): 497-514. http://dx.doi.org/10.2307/2389624.

Brancalion PHS, Isernhagen I, Machado RP, Christoffoleti PJ, Rodrigues RR. Seletividade dos herbicidas setoxidim, isoxaflutol e bentazon a espécies arbóreas nativas. Pesquisa Agropecuária Brasileira 2009; 44(3): 251-257. http://dx.doi. org/10.1590/S0100-204X2009000300005.

Brasil. Ministério da Agricultura, Pecuária e Abastecimento. Coordenação-Geral de Agrotóxicos e Afins/DFIA/SDA. Sistema de Agrotóxicos Fitossanitários - AGROFIT. AGROFIT - Consulta Aberta [online]. Brasília: AGROFIT; 2016 [cited 2016 Jun 29]. Available from: http://agrofit. agricultura.gov.br/agrofit_cons/principal_agrofit_cons.

Braz GBP, Oliveira RSD Jr, Constantin J, Takano HK, Godinho FB. Selectivity of herbicides applied in post-emergence of showy Crotalaria. Revista Caatinga 2016; 29(4): 918-926. http://dx.doi.org/10.1590/1983-21252016v29n417rc.

Brighenti AM, Muller MD. Tolerância de plantas de Khaya ivorensis e Toona ciliata a herbicidas. Floresta 2014; 44(4): 747-754. http://dx.doi.org/10.5380/rf.v44i4.32176.

Cantarelli EB, Machado SLO, Costa EC, Pezzutti L. Efeito do manejo de plantas daninhas no desenvolvimento inicial de Pinus taeda em várzeas na Argentina. Árvore 2006; 30(5): 711-718.

Cedergreen N. Herbicides can stimulate plant growth. Weed Research 2008; 48(5): 429-438. http://dx.doi. org/10.1111/j.1365-3180.2008.00646.x.

Duarte NF, Karam D, Sá N, Cruz MB, Scotti MRM. Selectivity of herbicides upon Myracrodruon urundeuva (Aroeira). Planta Daninha 2006; 24(2): 329-337. http:// dx.doi.org/10.1590/S0100-83582006000200016.

European Weed Research Council - EWRC. Committee of methods in weed research. Weed Research 1964; 4(1): 88. 
Grossmann K, Niggeweg R, Christiansen N, Looser R, Ehrhardt T. The herbicide saflufenacil (Kixor ${ }^{\mathrm{TN}}$ ) is a new inhibitor of protoporphyrinogen IX oxidase activity. Weed Science 2010; 58(1): 1-9. http://dx.doi.org/10.1614/ WS-D-09-00004.1.

Harker KN, O’Donovan JT. Recent weed control, weed management, and integrated weed management. Weed Technology 2013; 27(1): 1-11. http://dx.doi.org/10.1614/ WT-D-12-00109.1.

Hung CD, Trueman SJ. In vitro propagation of the African mahogany Khaya senegalensis. New Forests 2011; 42(1): 117-130. http://dx.doi.org/10.1007/s11056-010-9241-9.

Indústria Brasileira de Árvores - IBA. Relatório Anual 2016 [online]. São Paulo; Brasília: Ibá; 2016. [cited 2016 Sept 20]. Available from: http://iba.org/images/shared/ Biblioteca/IBA_RelatorioAnual2016_.pdf

Inoue MH, Pereira KM, Mendes KF, Santos EG, Dallacort R, Possamai ACS. Selectivity of herbicides for pinhão manso in conditions terms of greenhouse and field. Bioscience Journal 2014; 30(5): 791-801.

Lamprecht, H. Silvicultura nos trópicos: ecossistemas florestais e respectivas espécies arbóreas: possibilidades e métodos de aproveitamento sustentado. Eschbom: GmbH; 1990.

Mallory-Smith CA, Retzinger EJ Jr. Revised Classification of Herbicides by Site of Action for Weed Resistance Management Strategies 1. Weed Technology 2003; 17(3): 605-619. http://dx.doi.org/10.1614/0890-037X(2003)01 7[0605:RCOHBS]2.0.CO;2.

Monquero PA, Penha AS, Orzari I, Hirata ACS. Herbicides selectivity on seedlings of native species Acacia polyphylla, Enterolobium contortisiliquum (Fabaceae), Ceiba speciosa and Luehea divaricata (Malvaceae). Planta Daninha 2011; 29(1): 159-168.

Norsworthy JK, Ward SM, Shaw DR, Llewellyn RS, Nichols RL, Webster TM et al. Reducing the risks of herbicide resistance: best management practices and recommendations. Weed Science 2012; 60(sp1): 31-62. http://dx.doi.org/10.1614/WS-D-11-00155.1.

Oliveira RS Jr. Mecanismos de ação de herbicidas. In: Oliveira RS Jr, Constantin J, Inoue MH, editores. Biologia e manejo de plantas daninhas. Curitiba: Omnipax; 2011.
Pereira MRR, Martins D, Rodrigues ACP, Souza GSF, Cardoso LA. Selectivity of saflufenacil to Eucalyptus urograndis. Planta Daninha 2011; 29(3): 617-624. http:// dx.doi.org/10.1590/S0100-83582011000300016.

Pinheiro AL, Couto L, Pinheiro DT, Brunetta JMFC. Ecologia, silvicultura e tecnologia de utilização dos mognosafricanos (Khaya spp.). Viçosa: Sociedade Brasileira de Agrossilvicultura; 2011.

Pitelli RA, Marchi SR. Interferência de plantas daninhas nas áreas de reflorestamento. In: Anais do Seminário técnico sobre plantas daninhas e o uso de herbicidas em reflorestamento; 1998; Rio de Janeiro: Universidade Federal Rural do Rio de Janeiro; 1998. p. 44-64.

Rascher U, Liebig M, Lüttge U. Evaluation of instant lightresponse curves of chlorophyll fluorescence parameters obtained with a portable chlorophyll fluorometer on site in the field. Plant, Cell \& Environment 2000; 23(12): 1397 1405. http://dx.doi.org/10.1046/j.1365-3040.2000.00650.x.

Silva LFD, Ferreira GL, Santos ACAD, Leite HG, Silva MLD. Hipsometric, volumetric and growth equations for Khaya ivorensis, planted in Pirapora. Floresta e Ambiente 2016; 23(3): 326-368. http://dx.doi.org/10.1590/21798087.130715 .

Takahashi EN, Alves PLDCA, Salgado TP, Farias MA, Silva AC, Biaggioni BT. Consequences of clomazone and sulfentrazone drift on clones of E. grandis x E. urophylla. Revista Árvore 2009; 33(4): 675-683. http://dx.doi. org/10.1590/S0100-67622009000400010.

Tiburcio RAS, Ferreira FA, Ferreira LR, Machado MS, Machado AFL. Controle de plantas daninhas e seletividade do flumioxazin para eucalipto. Cerne 2012; 18(4): 523-531. http://dx.doi.org/10.1590/S0104-77602012000400001.

Zabkiewicz J, Steele KD, Welsh R, Mackisack G, Hagerty G, Zydenbos SM. Preliminary evaluation of salflufenacil herbicide for New Zealand forestry use. In: Annals of XVII Australasian weeds conference. New frontiers in New Zealand: together we can beat the weeds; 2010; Christchurch: New Zeland Plant Protection Society; 2010. p. 336-339. 